\title{
INELASTIC ANALYSIS OF REINFORCED CONCRETE STRUCTURES IN SCAD
}

\author{
Sergiy Yu. Fialko ${ }^{1,2}$, Anatolii V. Perelmuter ${ }^{2}$ \\ ${ }^{1}$ Tadeusz Kościuszko Cracow University of Technology, Krakow, POLAND \\ ${ }^{2}$ IT company SCAD Soft, Kyiv, UKRAINE
}

\begin{abstract}
This paper describes the approach implemented in SCAD for the analysis of behavior of fragments of thin-walled reinforced concrete structures taking into account the elastic-plastic behavior of both concrete and reinforcement.
\end{abstract}

Keywords: reinforced concrete structures, nonlinear analysis, stress-strain diagram

\section{РЕАЛИЗАЦИЯ НЕУПРУГОГО РАСЧЕТА ЖЕЛЕЗОБЕТОННЫХ КОНСТРУКЦИЙ В ПРОГРАММНОМ КОМПЛЕКСЕ SСАD}

\author{
С.Ю. Фиалко ${ }^{1,2}$, А.В. Перельмутер ${ }^{2}$ \\ ${ }^{1}$ Краковский технологический университет им. Тадеуша Костюшко, г. Краков, ПОЛЬША \\ ${ }^{2}$ НПО «СКАД Софт», г. Киев, УКРАИНА
}

\begin{abstract}
Аннотация: Представлен подход, реализованный в программном комплексе SCAD для анализа поведения фрагментов тонкостенных железобетонных конструкций с учетом упруго-пластической работы как бетона, так и арматуры.
\end{abstract}

Ключевые слова: железобетонные конструкции, неупругий расчет, диаграмма напряжение-деформация

The report describes the features of software implementation and new SCAD [7] modules for nonlinear analysis of thin-walled reinforced concrete structures based on a specially developed method [9].

It should be noted that in this case plastic behavior implies that loading and unloading are performed according to different laws and the residual deformations are taken into account. This is a fundamental difference from some developments where the so-called "physical nonlinearity" was used, which, in fact, reflects not the plastic behavior, but the nonlinear elasticity. Another important point is that all calculations are performed for a structure with specified reinforcement, i.e. we are dealing with a verification analysis (examination of the structural design).

The analysis of reinforced concrete structures taking into account the inelastic behavior of the material is implemented in SCAD by using special finite elements: a bar element, triangular and quadrangular shell elements (Figure 1).

When creating a design model the mode for specifying the reinforcement layout is used (Figure 2). It implies well-defined options for the placement of rebars, both in bar and in shell elements. The latter assume an orthogonal mesh design, the same orientation of the upper and lower reinforcement and the arrangement of rebars consistent with the direction of the alignment of forces $N_{x 1}$.

This corresponds to common cases of reinforcement design, although it narrows the fundamental possibilities of the calculation method, when the number of reinforcement layers in shells can be greater than four and the direction of reinforcement bars in each reinforcement layer can be arbitrary. 


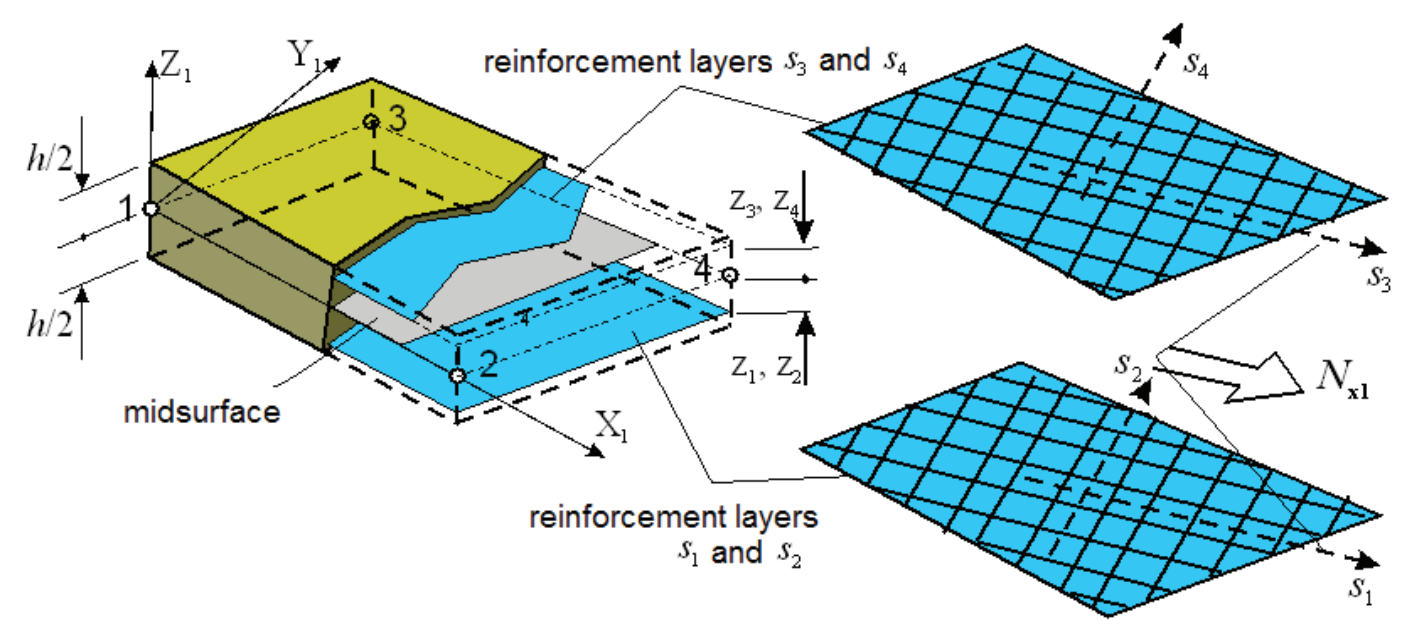

Figure 1. Four-node finite element for the calculation of reinforced concrete structures.

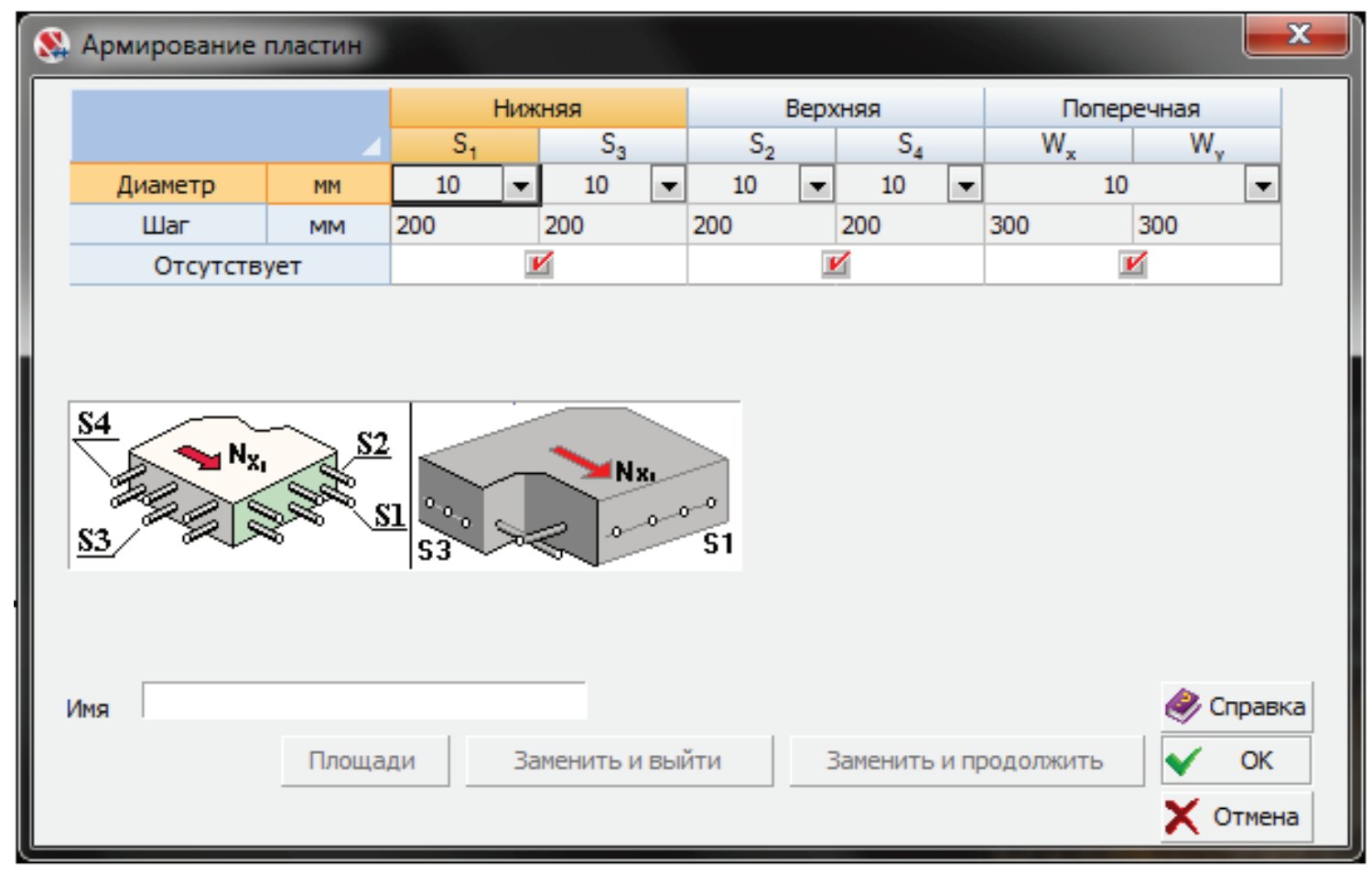

Figure 2. The "Reinforcement of Plates" dialog box.

This calculation mode is invoked by checking the

Physical nonlinearity checkbox in the Rigidities dialog box. If this checkbox is checked, the Materials dialog box appears, where you can specify the physical and mechanical properties of the material.

The software provides two options of the plastic behavior of the material:

- according to the strain theory of plasticity;

- according to the theory of plastic flow.
The strain theory of plasticity has given the best agreement with experiment in most tested cases. This option is used by default. In this case only the "stress-strain" diagram is required to describe the behavior of the system. The conditions of the elastic volume change and elastic unloading, as well as the proportionality of the stress deviator and the strain deviator, responsible for the shear and shape changes, respectively, are satisfied. 


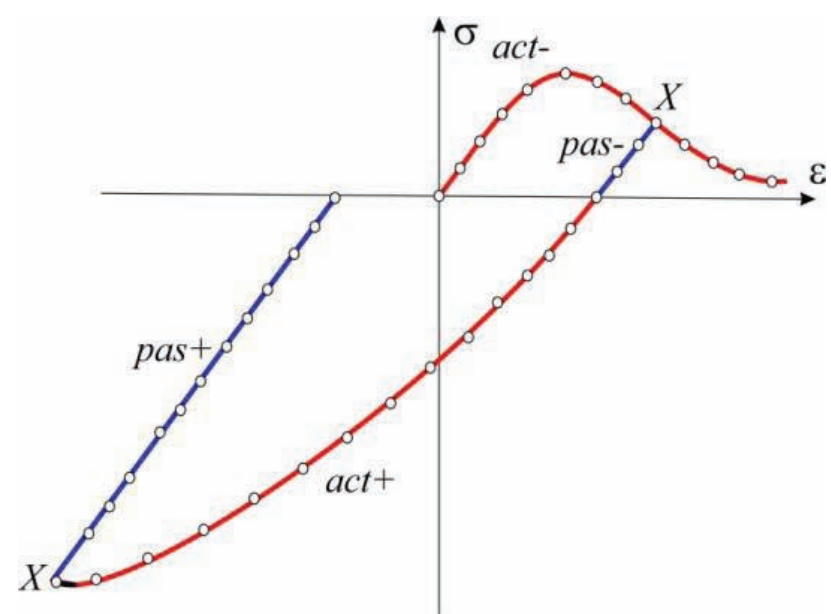

Figure 3. The $\sigma-\varepsilon$ diagram: act- - active loading in the tension area; pas- - unloading in the tension area; act + -active loading in the compression area; pas +- unloading in the compression area; $X$-start of unloading.

In the second case, the behavior of the system also defines the yield surface, which in the program can be represented either by the Drucker-Prager plasticity condition [1] or by the Genie's plasticity condition [5].

The stress-strain relationship with a descending branch in the tension area can be used to describe the behavior of concrete (Figure 3). The degradation of concrete caused by crack opening is modeled in this way. It is known that the presence of a descending branch of the $\sigma-\varepsilon$ diagram is a source of instability of computational algorithms. The approach implemented in SCAD is based on the fact that only reinforced concrete (and not concrete) structures are considered, and the reinforcement, the $\sigma-\varepsilon$ diagram for which does not have any descending regions, regularizes the numerical solution.

Since in the numerical implementation of a nonlinear problem, an arbitrary assignment of the $\sigma-\varepsilon$ diagram can lead to a lack of convergence (see for example [4]), they are automatically reduced to a form that ensures the stability of the computational process. For this purpose, the parameter $\xi$ is used, which specifies the length of the descending branch (Figure 4).

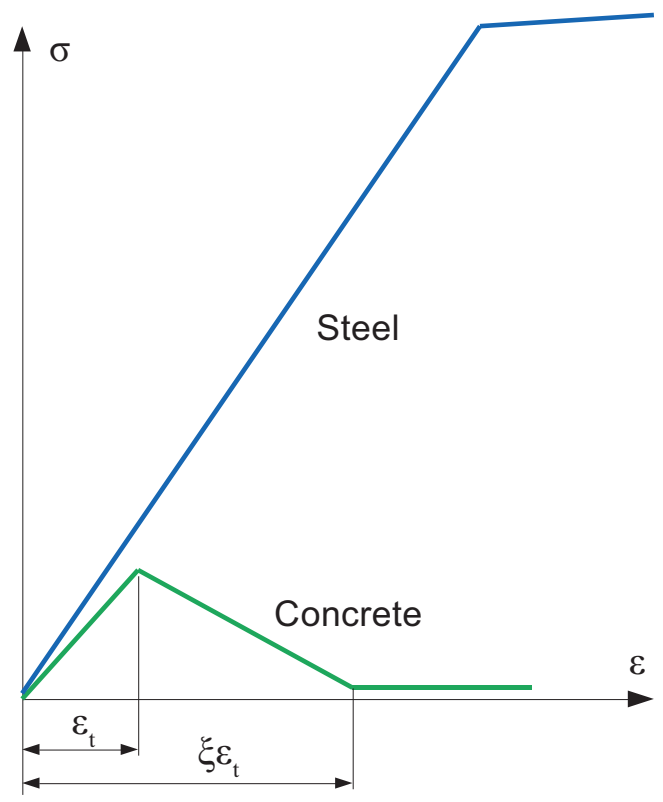

Figure 4. Regularization parameter.

The role of the parameter $\xi$ is illustrated by a simple example of a tensile reinforced concrete bar (Figure 5).

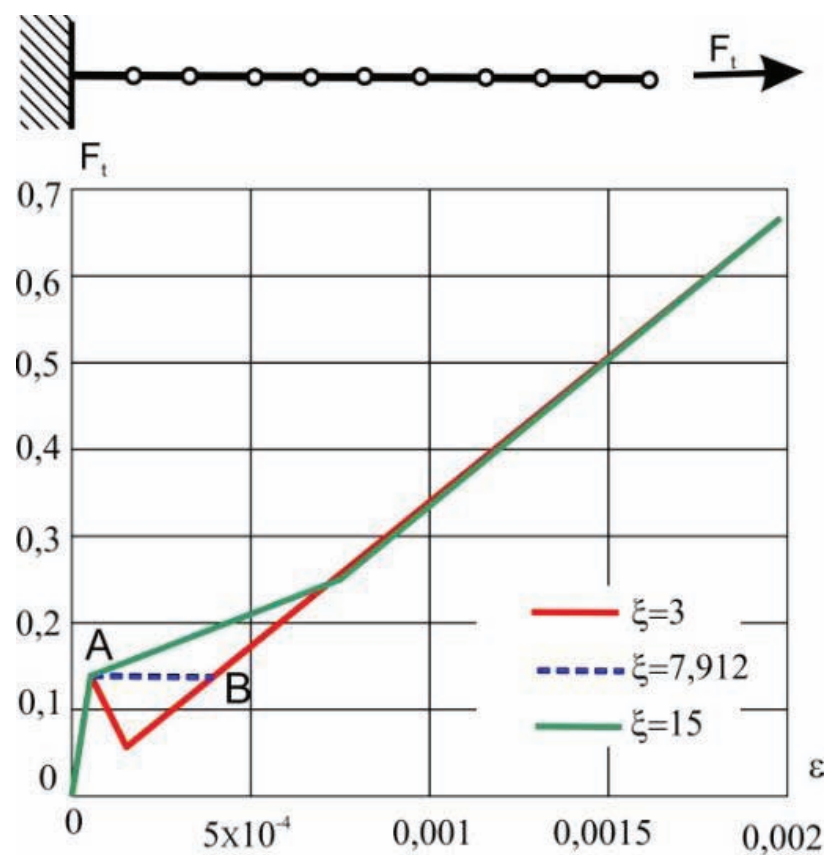

Figure 5. Tension of a reinforced concrete bar.

When $\xi=15\left(\xi>\xi_{\min }\right)$ the equilibrium curve increases monotonically and corresponds to stable equilibrium states at all points. When $\xi=$ $\xi_{\min }=7.912$ the equilibrium curve has a plateau. 
When $\xi=3\left(\xi<\xi_{\min }\right)$ a descending region appears on the equilibrium curve, corresponding to unstable equilibrium states. Therefore, a jump occurs from the point $\mathrm{A}$, which corresponds to the beginning of the descending branch of the $\sigma$ $\varepsilon$ diagram for concrete, to a new stable equilibrium state (point B). Here

where

$$
\xi_{\min }=1+\mathrm{E} /\left(\mu_{\mathrm{s}} \mathrm{E}_{\mathrm{s}}\right)
$$$$
\mu_{\mathrm{s}}=\mathrm{A}_{\mathrm{s}} / \mathrm{A}
$$

is the reinforcement ratio, $\mathrm{A}$ is the concrete area, $\mathrm{A}_{\mathrm{s}}$ is the reinforcement area [9].

In the considered simple problem the jump from point $\mathrm{A}$ to point $\mathrm{B}$ occurs simultaneously for all finite elements when $\xi<\xi \min$. However, in real problems such jumps in different finite elements occur at different values of the load parameter. The equilibrium curve contains many regions corresponding to unstable equilibrium states, and obtaining the correct numerical solution for such a problem becomes too time-consuming. Therefore, the program always takes $\xi>\xi \mathrm{min}$.

Allowing for the degradation of concrete in the tension area during cracking when obtaining the numerical results for the curve $a$ can lead to a time-consuming solution. Obtaining the numerical results for the curves $b$ and $c$ without taking into account the degradation of concrete and the strength of concrete in the tension area (Figure 6) is significantly less time-consuming.

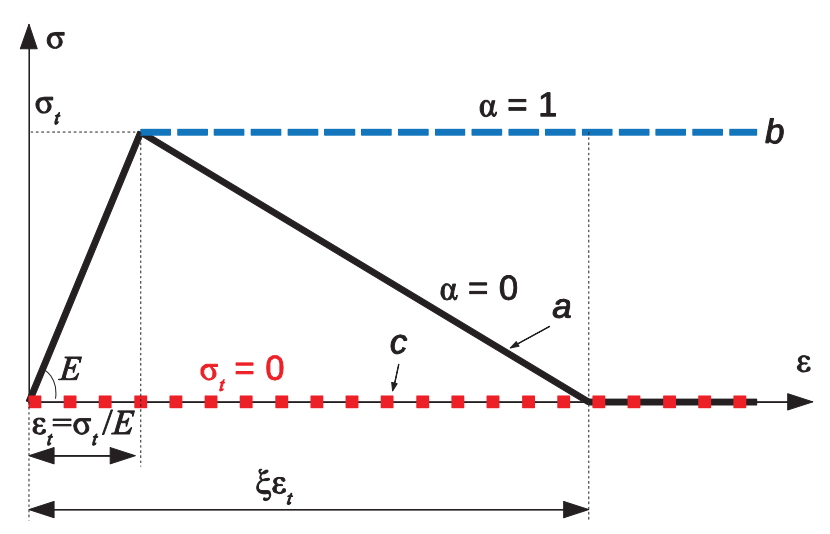

Figure 6. Diagrams for concrete in the tension area.

The performed calculations show that the curve $b$ gives an upper-bound estimate of the solution, and the curve $c$ gives a lower-bound estimate. If the difference between the curves $b$ and $c$ turns out to be small, then we can take the curve $c$ as the final result, when using the curve $a$ leads to considerable computational difficulties.

The work of the program can be illustrated by the analysis of a fragment of a multistory building (Figure 7). The design model was created from triangular and quadrangular shell elements [3].

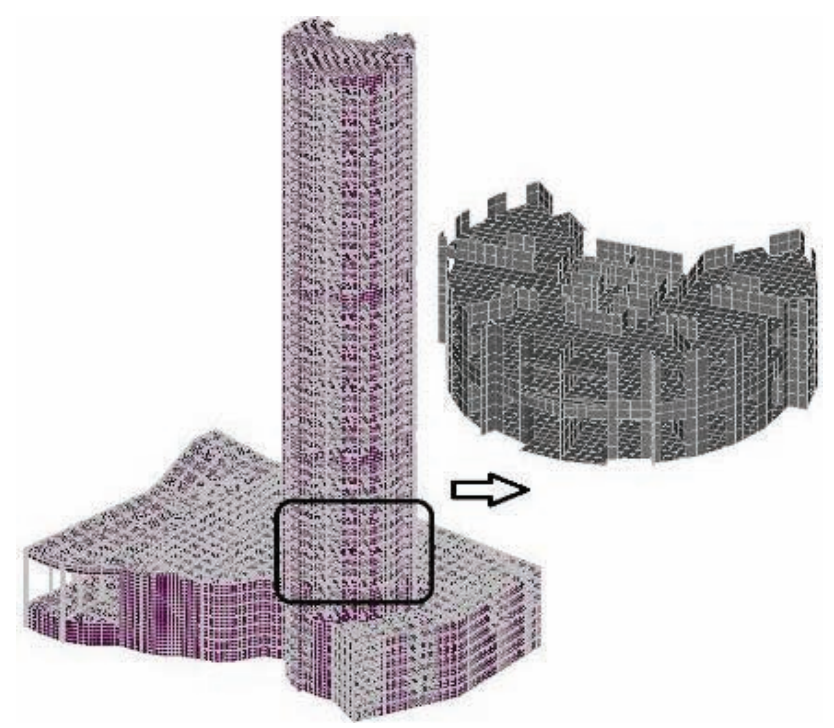

Figure 7. Multistory building fragment.

The results of the calculation enable to detect critical states of finite elements, which in turn indicate that the structure has experienced some irreversible changes. It means that the finite element has reached its limit state, but the system may still be serviceable.

Figure 8 shows critical events in the considered example. Apparently, such states of the structure require close attention. It can only be noted here, that this problem is not solved in the design codes, which consider the plastic redistribution of forces only in particular cases.

Calculations performed when testing the software have indicated some unusual results:

1. When there are developed deformations, some floor slab elements turn out to be tensile! This effect is caused by the fact that strong walls form a closed loop for the floor. The applied vertical load from the weight of the above floors compresses the walls in the vertical direction, simultaneously causing the lateral expansion. 

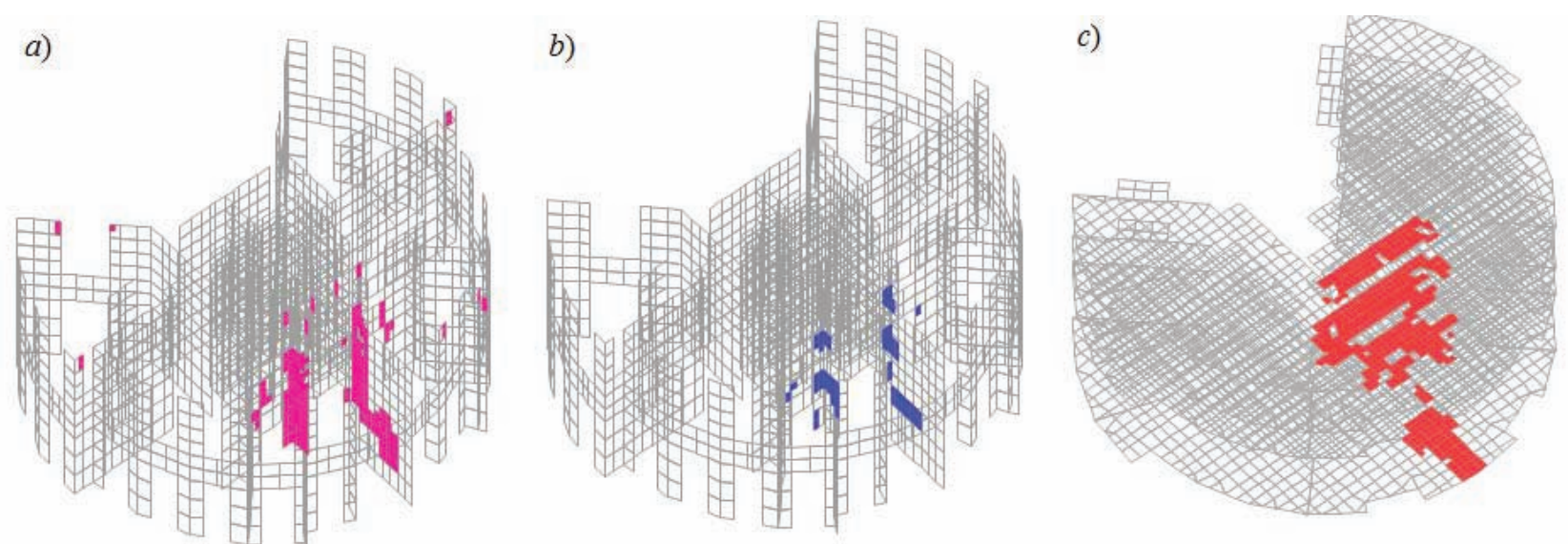

Figure 8. Results of the calculation: a - the reinforcement of the compression area has reached the yield point; $b$ - the concrete of the compression area has reached the yield point; $c$ - the reinforcement of the tension area has reached the yield point.

2. Due to the fact that when plastic deformations develop, the tangential stiffness of concrete is distributed asymmetrically across the section height, and also in the case of asymmetrical reinforcement, nonzero components appear in the stiffness matrix of a finite element relating membrane and bending internal forces.

Tension-compression stresses and shear stresses arise while transverse bending. At the same time when internal forces act at the middle surface the transverse bending is manifested. None of this is true for elastic finite elements from a homogeneous material.

Finally, let us point out some general problems that arise in the nonlinear structural analysis. In particular, the nonlinear analysis can be extremely challenging for the majority of SCAD users since their professional experience is based on linear problems. It should also be noted that there is a contradiction between the results of the refined elastoplastic calculation and the rule for applying the method of design limit states, where the safety factors are justified by the linear probabilistic analysis.

After all, both the distribution of internal forces and the strength parameters are defined by the same diagram of the material behavior, so the question arises about the possibility of their separate consideration (Figure 9).

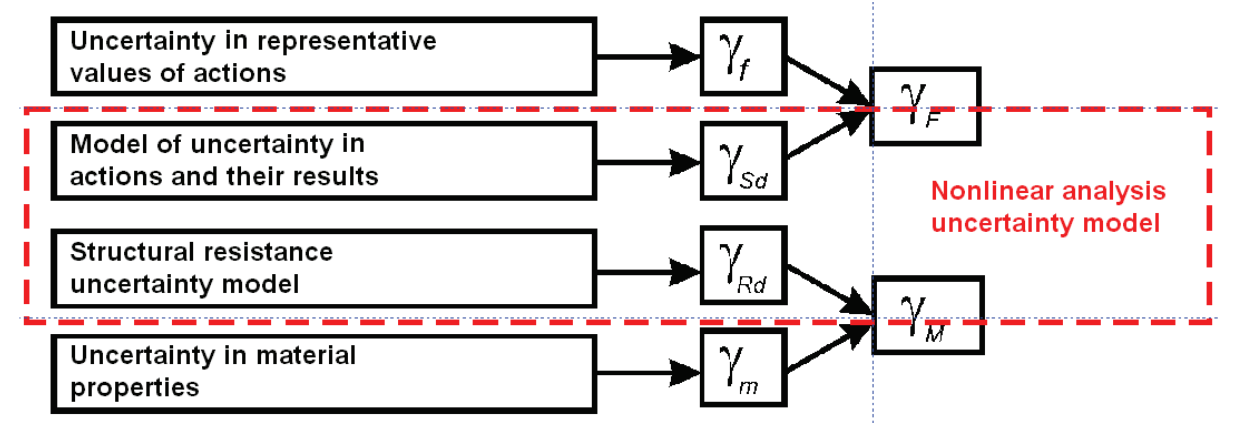

Figure 9. Selection of design factors.

A complete transition to nonlinear analysis is hardly possible due to the fundamental difficulties arising here [8]. And the long history of using the linear calculations, apparently, speaks in favor of the fact that they should not be abandoned yet. Nonlinear analysis should serve as an auxiliary tool to complement and clarify the results of linear calculations. 
For example, when designing a high-rise complex "Federation" in Moscow [6], all linear calculations were preliminarily performed, and the peculiarities of the structural behavior were determined. And only then was the behavior of the considered fragments refined taking into account the nonlinear behavior of reinforced concrete.

\section{REFERENCES}

1. Drucker D.C., Prager W. Soil Mechanics and Plastic Analysis or Limit Design. // Quaterly of Applied Mathematics, 1952, Vol. 10, pp. 157-165.

2. Fialko S.Yu. Quadrilateral Finite Element for Analysis of Reinforced Concrete Floor Slabs and Foundation Plates. // Applied Mechanics and Materials, 2015, Vols. 725726, pp. 820-835.

3. Fialko S.Yu., Karpilovskyi V.S. Triangular and Quadrilateral Flat Shell Finite Elements for Nonlinear Analysis of Thin-Walled Reinforced Concrete Structures in SCAD Software. // Shell Structures: Theory and Applications, Vol. 4. (ed. Pietraszkiewicz W. and Witkowski W.) CRC Press Taylor \& Francis Group, London, New York. 2017, pp. 367-370.

4. Kayhan E. Application of Viscous and Non-Local Integral Type Regularization Schemes for Softening Plasticity. Master's Thesis. Manufacturing Engineering Atilim University, 2009.

5. Geniev G.A., Kissyuk V.N., Tupin G.A. The Theory of Plasticity of Concrete and Reinforced Concrete. Moscow. Stroyizdat, 1974. 306 pages (in Russian).

6. Karpenko N.I., Karpenko S.N., Travush V.I. O Metodah Rascheta Vysotnyh Zdanij i Sooruzhenij iz Monolitnogo Zhelezobetona na Osnove Poslojnoj Detalizacii [On the Methods for Analysis of High-Rise Buildings and Structures from Monolithic Reinforced Concrete on the Basis of Layered Detailing]. // Sovremennoe
Promyshlennoe $i$ Grazhdanskoe Stroitel'stvo, 2011, Vol. 7, No. 3, pp. 147163 (in Russian).

7. Karpilovsky V.S., Kriksunov E.Z., Malyarenko A.A., Perelmuter A.V., Perelmuter M.A., Fialko S.Yu. SCAD Office. Versija 21 Vychislitel'nyj Kompleks SCAD++ [SCAD Office. Version 21. SCAD++]. Moscow, SCAD Soft, ASV Publishing House, 2015, 848 pages (in Russian).

8. Perelmuter A.V., Tur V.V. Gotovy li My Perejti k Nelinejnomu Analizu pri Proektirovanii? [Whether we are Ready to Proceed to a Nonlinear Analysis at Designing?]. // International Journal for Computational Civil and Structural Engineering, 2017, Volume 13, Issue 3, pp. 86-102.

9. Fialko S.Yu. Primenenie Metoda Konechnyh Jelementov k Analizu Prochnosti i Nesushhej Sposobnosti Tonkostennyh Zhelezobetonnyh Konstrukcij s Uchetom Fizicheskoj Nelinejnosti [Application of Finite Element Method to Analysis of Strength and Bearing Capacity of Thin-Walled Concrete Structures, Taking into Account the Physical Nonlinearity]. Moscow, SCAD Soft, ASV Publishing House, 2018.

\section{СПИСОК ЛИТЕРАТУРЫ}

1. Drucker D.C., Prager W. Soil Mechanics and Plastic Analysis or Limit Design. // Quaterly of Applied Mathematics, 1952, Vol. 10, pp. 157-165.

2. Fialko S.Yu. Quadrilateral Finite Element for Analysis of Reinforced Concrete Floor Slabs and Foundation Plates. // Applied Mechanics and Materials, 2015, Vols. 725726, pp. 820-835.

3. Fialko S.Yu., Karpilovskyi V.S. Triangular and Quadrilateral Flat Shell Finite Elements for Nonlinear Analysis of Thin-Walled Reinforced Concrete Structures in SCAD 
Software. // Shell Structures: Theory and Applications, Vol. 4. (ed. Pietraszkiewicz W. and Witkowski W.) CRC Press Taylor \& Francis Group, London, New York. 2017, pp. 367-370.

4. Kayhan E. Application of Viscous and NonLocal Integral Type Regularization Schemes for Softening Plasticity. Master's Thesis. Manufacturing Engineering Atilim University, 2009.

5. Гениев Г.А., Киссюк В.Н., Тюпин Г.А. Теория пластичности бетона и железобетона. - М.: Стройиздат, 1974. $316 \mathrm{c}$.

6. Карпенко Н.И., Карпенко С.Н., Травуш В.И. О методах расчета высотных зданий и сооружений из монолитного железобетона на основе послойной детализации. // Современное промышленное и гражданское строительство, 2011, том. 7, №3, с. 147163.

7. Карпиловский В.С., Криксунов Э.З., Маляренко А.А., Перельмутер А.В., Перельмутер М.А., Фиалко С.Ю. SCAD Office. Версия 21 Вычислительный комплекс SCAD++. - М.: Издательство ACB, 2015. - $848 \mathrm{c}$.

8. Перельмутер А.В., Тур В.В. Готовы ли мы перейти к нелинейному анализу при проектировании? // International Journal for Computational Civil and Structural Engineering / Международный журнал по расчету гражданских и промышленных конструкиий, 2017, Volume 13, Issue 3, pp. 86-102.

9. Фиалко С.Ю. Применение метода конечных элементов к анализу прочности и несущей способности тонкостенных железобетонных конструкций с учетом физической нелинейности. - М.: АСВ, 2018. - 192 c.

Sergey Yu. Fialko, Professor, Dr.Sc., Department of Physics, Mathematics and Applied Computer Science, Cracow University of Technology; 24, ul. Warszawska, Kraków 31-155, Poland; tel. +48 1262820 00; fax +48 1262820 71; e-mail: sergiy.fialko@gmail.com, sfialko@poczta.onet.pl.

Anatolii V. Perelmuter, Foreign member of the Russian Academy of Architecture and Construction Sciences (RAACS), Doctor of Science, Professor; SCAD Soft Ltd; office 1,2, 3a Osvity street, Kiev, 03037, Ukraine; phone: +38 0442497193 (91), +38 0442487100 , +38 04424880 60; e-mail: avp@scadsoft.com.

Фиалко Сергей Юрьевич, профессор, доктор технических наук, кафедра физики, математики и прикладных компьютерных наук, Краковский политехнический университет; 24, ul. Warszawska, Kraków 31-155, Poland; тел. +48 1262820 00; факс +48 1262820 71; e-mail: sergiy.fialko@gmail.com, sfialko@poczta.onet.pl.

Перельмутер Анатолий Викторович, иностранный член Российской академии архитектуры и строительных наук (РААСН), профессор, доктор технических наук; НПО СКАД Софт; 03037, Украина, г. Киев, ул. Просвещения (Освиты), 3а, к. 1,2; тел.: +38 0442497193 (91), +38 0442487100 ,

+38 04424880 60; e-mail: avp@scadsoft.com. 